\title{
The importance of introducing medical legislation in the university training program for students
}

\author{
George Nicola', Irina Maria Gheorghiu², Sanziana Scarlatescu³, Paula Perlea ${ }^{3}$ \\ ${ }^{1}$ Department of Medical Legal Elements and Malpractice, Faculty of Medicine, \\ "Carol Davila" University of Medicine and Pharmacy, Bucharest, Romania \\ ${ }^{2}$ Department of Restorative Dentistry, Faculty of Dental Medicine, \\ "Carol Davila" University of Medicine and Pharmacy, Bucharest, Romania \\ ${ }^{3}$ Department of Endodontics, Faculty of Dental Medicine, \\ "Carol Davila" University of Medicine and Pharmacy, Bucharest, Romania
}

\begin{abstract}
The place of medical legislation in the university curriculum remains somehow uncertain and should be identified more clearly. A more robust knowledge base on the law is needed to enable medical students to develop sufficient legal competence to manage the challenges of future practice. Further research is needed to identify the most effective methods of teaching, learning and assessing legal knowledge and skills, during and after the completion of initial medical education. An in-depth analysis of resources shows that there is no robust evidence base that evaluates the impact in different curricular structures of the efficient methods in developing the knowledge, skills, attitudes, and behaviors needed in medical practice of student. Moreover, only a limited number of studies refer to the results and effectiveness of teaching and learning the elements of medical legislation.
\end{abstract}

Keywords: medical legislation, university curriculum, training program

\section{INTRODUCTION}

In Romania, to perform a medical act implies some risks of medical malpractice failing to know and not respecting the legal framework that applies to medical practice. And this is because doctors do not know or know only partially, the legal framework that regulates their activity, in the relationship with patients. Thus, the medical practice is often based on „customary low" passed down through generations of professionals, without anyone verifying the validity of this information [1]. This is easy to understand because until 2017 in our country there was no training on medical legislation in the university or postgraduate program.

A fundamental issue that needs to be addressed is the proper education and training of future doc- tors in the legislative field, in order to enable them to carry out their profession effectively on the workplace, while respecting the rights of patients [2]. University students should be aware of the importance of the legislative framework, understand the errors created by not knowing it and should acquire the knowledge and skills necessary to increase the prevention of mistakes arising from the ethical-legal component of the medical act $[3,4]$.

This begs the question: is the university curriculum, regarding medical legislation, ready to meet the educational needs of the student's education? Is it clear for university education "what", "how" and "where"can be learned to comply the skills to respect legislative framework or is it ready to integrate such learning in the curriculum? 


\section{THE IMPORTANCE OF TEACHING MEDICAL LEGISLATION IN MEDICAL EDUCATION}

Analyzing the literature we see that there are surprisingly few studies on the effectiveness of teaching and learning medical legislation in university medical education [5-9].

An image of the current state of knowledge in the field of the approached topic and also the stages of the scientific approach will be explored in this paper. The final objective - the necessity to introduce the medical legislation in the university curriculum - in order to be fulfilled, must start from the educational needs of the students correlated with the vulnerabilities in the medical practice but also how this should happen. The most effective methods of teaching, learning and assessment of students are presented.

Even after the academic and clinical settings are aligned, due to the fast changes in legislation, the educational needs have to be quickly updated: hence the need for postgraduate programs to prepare doctors for medical practice, and these in turn, through the accumulated experience, to contribute to the elaboration of the new legal norms. The results can be the starting point for other educational programs, and these programs may or may not be part of the same university curriculum.

The moral norms, which form the basis of biomedical ethics, proposed by Beauchamp and Childress, correspond to the common moral norms of society and try to guide the solution of concrete problems of medical staff in practice. These norms are represented by: the principle of autonomy, the principle of non-harm, the principle of benefit and the principle of justice [10].

Therefore, as a necessity, the regulation of medical practice covers the following areas: the patient's rights, the correlative obligations of the doctor/health institutions and the organization of activities in the medical field.

Maybe we should first look at the global picture, take example from world's universities where these educational programs already have gained a lot of experience.

In some national and international declarations of university programs and accreditation programs of medical institutions, we find the need for medical staff to present solid knowledge about medical legislation and its understanding [11,12].
Thus, in the USA, considering that in the 1970s, 40 of the 101 medical schools reported the teaching of legislative notions, today, due to the increasing number of legal problems in medical practice, these courses are offered at all 127 medical schools, being present in all school programs, optional (in 54 programs) or compulsory (74.8\%) [13-15].

In the United Kingdom, the General Medical Council (GMC), since the 1990s, requires doctors to have knowledge of medical legislation and to respect it in medical practice. These standards can be met only if the teaching and learning of the notions of legislation in medical schools are integrated both vertically and horizontally, in the school curriculum [16]. Good medical practice inevitably raises both ethical and legal issues and requires the understanding of both [17].

If in Australia and New Zealand the standards require knowledge of the legal responsibilities in the medical profession, in Canada you need to understand in a more comprehensive way, notions of legislation related to practice [18]. The content of these legislative notions refers to: confidentiality, consent, avoidance of discrimination, patients' access to data [19-21].

The basic purpose of this learning must be to create a necessary core of skills, knowledge, attitudes and behaviors for the practice of future physicians. Obviously, another natural question arises: what are the most effective methods of teaching, learning and evaluating students? Are medical universities ready to develop their capacity to teach the legislative elements and the notions of medical malpractice in the university study process?

Therefore, for a good university curriculum first it must identify the educational needs of students related to vulnerabilities in medical practice, then the most effective methods of teaching, learning and assessment of students in the field of medical legislation, adapted to educational needs to permanent legislative changes.

Empirical studies of teaching the legal medical legislation are characterized by an insufficient sample size and are focused on individual study programs. There are based on student satisfaction measures and the evaluation of short-term outcomes, without assessing if knowledge is retained on time and if learning has an impact on the patient. Studies reveal a lack of coordination between pre-clinical and clinical education. 
The emphasis, throughout the literature, is on the acquisition of knowledge and understanding, mainly on ,what" and less on ,how”, which also requires technical competence in the development of analytical thinking about legal rules (,why "). Less prominent are conceptual development and research on the application of legal knowledge to problem-solving and legislation-based reasoning [19].

There is some evidence that teaching and evaluating the law improves legal knowledge and understanding, but it requires consolidation and continuous development, both before and after the initial qualification, through formal training and greater access to up-to-date of medical legislation information.

Although there is evidence of the development of students' knowledge, many courses applied in the preclinical years are considered far from the practice in which its application would be tested. Learning the legislation in the years with clinical practice seems to be opportunistic but not structured. Let us remember the „customary low” that can be taken as the „norm” before learning this knowledge of medical legislation. That is why in most universities in the world, this knowledge is taught in the preclinical years.

From all the documentation, the summarised data is that medical students should be taught about these medical notions, because as future doctors should know about: valid consent, how to obtain it, how to proceed if a patient is just partially competent or incompetent to consent or refuse treatment, confidentiality, discrimination, access to medical records, filming and photographing the patient, access to the second opinion, limitation to their own specialty.

In this context, differences in the emphasis on legislation from the moral and ethical point of view in common clinical practice, public health, health promotion and disease prevention can be considered appropriate elements of the university curriculum.

Some national and international programs state and require medical students and practicing physicians to have solid knowledge and understanding of medical legislation. Consequently, the notions of medical legislation appear as a basic component of the university program, in order to ensure the qualified application by the medical staff (doctors, dentists, nurses, midwives, pharmacists) of a correct understanding of their legal obligations, for a safe and effective practice.

A unanimous opinion is that any medical decision involves two components: a technical component that requires the application of basic scientific knowledge and an ethical-legal component; that requires that the scientifically correct decision must be legally justifiable. Teaching and learning these notions must also show the direct consequences of lack of knowledge in this field (injury to the patient or exclusion to payment from malpractice insurance) and the importance of the existence of professional training in this regard [22,23].

Barriers against the integration of notions of medical legislation include overcrowded existing curricula, which lead to variable allocations of discrete courses and hours, financial constraints, lack of expertise and specific legal knowledge [17,24].

Briefly, the final goal of introducing the notions of medical legislation in the university curriculum must take into account:

1. Supporting education for medical legislation and malpractice by creating and disseminating program resources at the university level, in order to facilitate the university training of doctors and prepare them for safe practice on the workplace;

2 . To provide a university program that can be easily adapted to suit the ever-changing educational needs of medical students and educators on medical legislation;

3. To encourage medical universities to develop their capacity to teach legislative elements and notions of malpractice;

4. Ensure that the university curriculum is appropriate to the socio-cultural context and is applicable to the various university education systems in the country for health;

5. To sensitize the opinion of the medical staff (of the doctors in particular) and to ensure the teaching and learning of the legislative framework for medical practice.

\section{CONCLUSIONS}

Students and young doctors must have a good understanding of their professional and legal responsibilities, otherwise, they may absorb unacceptable habits and attitudes with adverse effects 
on their medical practice in the clinic, especially if they encounter "outdated role models". Learning the notions of medical legislation in the years associated with clinical practice can be harmful because they can adopt as a "norm" these "customary low", eventually ending up having inadequate medical conduct. That is why we cannot agree with the idea that "seniority in practice" is a guarantee of the legally correct perception and attitude in medical practice.

The ultimate goal, translated as their "juridical literacy“, is for students to develop certain ,positive attitudes" towards the law, to acquire certain

\section{REFERENCES}

1. Nanu A, Georgescu D, Voicu V, loan B. Place and relevance of Legal Provisions in the background of medical practice in Romania. Revista Română de Bioetică 2011;9(4):90-110.

2. Legea 95/2006 privind reforma în domeniul sanitar, art. 642, alin. 4, art. 649 , alin.1.

3. Nanu A. Teza de doctorat „Malpraxisul - consecinţe şi impact în plan moral şi juridic asupra practicii medicale din România", Academia Română, 2008

4. Nanu A (coord.). Malpraxisul medical -7 instrucțiuni de siguranță în practica medicală. Ediția a 2-a, București: MedRight Experts, 2013.

5. Liaison Committee on Medical Education. Functions and Structure of a Medical School. Standards for Accreditation of Medical Education Programs Leading to the MD Degree. Washington, DC: Association of American Medical Colleges 2010.

6. Liaison Committee on Medical Education. General Instructions for Completing the Database for Provisional Accreditation. Washington, DC: Association of American Medical Colleges 2009.

7. Persad G, Elder L, Sedig L, Flores L, Emanuel E. The current state of medical school education in bioethics, health law, and health economics. J Law Med Ethics. 2008;36:89-94.

8. Walrond E, Jonnalagadda R, Hariharan S, Moseley H. Knowledge, attitudes and practice of medical students at the Cave Hill Campus in relation to ethics and law in healthcare. West Indian Med J. 2006;55:42-7.

9. Scott C, Barrows H, Brock D, Hunt D. Clinical behaviours and skills that faculty from 12 institutions judged were essential for medical students to acquire. Acad Med. 1991;66:106-11.

10. Beauchamp TL, Childress JF. Principles of Biomedical Ethics, 6th edition. Oxford University Press, 2009;1;12-13.

11. Ashcroft R, Baron D, Benatar S, et al. Teaching medical ethics and law within medical education: a model for the UK core curriculum. Consensus statement by teachers of medical ethics and law in UK medical schools. J Med Ethics. 1998;24:188-92.

12. Australian Medical Council. Assessment and Accreditation of Medical Schools: Standards and Procedures. Kingston, ACT: AMC 2009. skills to facilitate judgment and to make justifiable decisions, primarily legal and professional.

The impact of teaching the notions of medical legislation is completed in practice and can be measured by changes in individual behavior, changes in organizational behavior and benefits for the patient, this being in fact the main beneficiary of these changes.

\section{Acknowledgement}

For this article all the authors have equal contributions.

Conflict of interest: none declared Financial support: none declared

13. Olick RS. It's Ethical, But Is it Legal? Teaching Ethics and Law in the Medical School Curriculum; The Anatomical Record (New Anat.) 2001;265:5-9.

14. American Medical Association, Council on Ethical and Judicial Affairs. 1998-1999. Code of Medical Ethics: Current Opinions with Annotations. Chicago: American Medical Association.

15. American College of Physicians. 1998. Ethics Manual, 4th edition. Ann Int Med. 128:576-594.

16. General Medical Council. Tomorrow's doctors: outcomes and standards for undergraduate medical education. London: GMC 2009.

17. Stirrat GM, Johnston C, Gillon R, et al. Medical ethics and law for doctors of tomorrow: the 1998 Consensus Statement updated. J Med Ethics. 2010;36:55-60.

18. Association of Teachers of Ethics and Law in Australian and New Zealand Medical Schools. An ethics core curriculum for Australasian Medical Schools: a working group on behalf of ATEAM. Med J Aust. 2001;175:205-10.

19. Preston-Shoot M, McKimm J. Towards effective outcomes in teaching, learning and assessment of law in medical education. Medical Education. 2011;45:339-34.

20. Patey R, Flin R, Ross S, Parker S, Cleland J, Jackson J, Moffat M, Thomson A. WHO Patient Safety Curriculum Guide for Medical Schools; Evaluation Study, Report to WHO Patient Safety Programme; August 2011.

21. The WHO Patient Safety Curriculum Guide for Medical Schools, February 2009.

22. Nicola G, Gheorghiu IM, Scarlatescu S, Constantinescu FE, Perlea P. Managing the relationship with the press in the context of medical malpractice accusation. Rom J Leg Med. 2020;28:348-354.

23. Nicola G, Gheorghiu IM, Scarlatescu S, Mitran L, Mitran M. Reforma practicii medicale: abordare istorică, responsabilităţi legale, legislaţie actuală. Orl.ro. 2021;50(1).

24. Rhodes R, Cohen DS. Understanding, being, doing: medical ethics in medical education. Camb Q Healthc Ethics. 2003;12:39-53. 